\title{
Reklam Beğenilirliğine Yönelik Bir Model Önerisi'
}

\section{Sefa ERBAȘ ${ }^{23}$}

\section{Öz}

Bu çalışmada; bir televizyon reklamına yönelik beğeniyi oluşturan değişkenlerin belirlenmesi ve her bir değişkenin reklam beğenilirliği üzerine etkisini bir model aracılığı ile göstermek amaçlanmıştır. Araştırma, Tadım Markasının 'Türkiye'nin En Büyük Sosyal Ağı' reklamını izleyen farklı yaş gruplarına sahip 300 denekle gerçekleştirilmiştir. Araştırma kapsamında geliştirilen modelde yer alan; demografik veriler, kişilik özellikleri, reklama yönelik tutum, markaya yönelik tutum ve yaratıcı strateji değiş̧kenlerinin beğeni üzerine etkisi, hiyerarşik regresyon analizi ile test edilmiştir. Bu değişkenlerden sadece reklama yönelik tutum ile yaratıcı strateji değişkenlerinin beğeniyi açıklamada istatistiki olarak anlamlı olduğu sonucuna ulaşılmıştır. Reklam beğenilirliğini belirleyen değişkenlerin bir model aracılığı ile incelendiği bu çalışmanın, alanda araştırma yapan akademisyenlere ve pazarlama uygulayıcılarına önemli bir katkı sağlamada öncü rol üstleneceği düşünülmektedir.

Anahtar Kelimeler: Reklam Beğenilirliği, Bir Reklama Yönelik Tutum, Nicel Araştırma Yöntemi, Hiyerarşik Regresyon.

ATIF: Erbaș, S. (2019). Reklam Beğenilirliğine Yönelik Bir Model Önerisi. Akdeniz Üniversitesi Iletișim Fakültesi Dergisi, 32, s. 621-641

\footnotetext{
1 Bu makale, araştırmacının Eskişehir Anadolu Üniversitesi Sosyal Bilimler Enstitüsü Halkla İlişkiler ve Reklamcılık Programında hazırladığı 'Reklam Beğenilirliği' adlı doktora tezinden birebir üretilmiş olup, II. Uluslararası Sosyal Bilimler ve Inovasyon Kongresi'nde (SOS-CON 2019, 26-28 Nisan, Elazığ) sunulan ve özet kitabında basılan çalışmanın tam metnidir.

2 Dr. Öğr. Üyesi, Gümüşhane Üniversitesi Edebiyat Fakültesi, Psikoloji Bölümü, sefaerbas@gmail.com ORCID: 0000-0003-3905-9248

3 Sorumlu Yazar / Corresponding Author
} 


\title{
A Model Proposal for Ad Likeability
}

\begin{abstract}
The aim of this study is to identify the variables of ad likeability of commercials, and to find out the impact of each variable on ad likeability through a model. The research was carried out with 300 participants from different age groups who had watched the "Turkey's Largest Social Network" TV commercial of brand Tadım. The impact of the variables such as demographic data, personality traits, attitude toward ad, attitude toward brand and creative strategies in the model developed in the context of the research on the ad likeability were tested through hierarchical regression analysis. It was concluded that only the variables of attitude toward ad and creative strategy were statistically meaningful in explaining ad likeability. This study, which has examined the variables determining the ad likeability through a model, is thought to be a pioneering study to make a significant contribution to the researches carried out by academicians and marketing practitioners in the field.
\end{abstract}

Keywords: Ad likeability, Aad, Quantitative method, Hierarchical regression.

\section{Giriș}

Pazar alanının global bir oyun sahası haline gelmesi ile ürünler, markalar ve semboller dünya genelinde tüketicinin günlük yaşamının bir parçası haline gelmeye başladı. Levitt (1983) "Pazarların Globalleşmesi" adlı makalesinde tüketicilerin hangi kültüre ait olduğuna bakılmaksızın benzer reklam çekicilikleri ve değerleri yoluyla ikna edilebildiğini, dünyanın bir benzer kültür (homocultural) pazar alanına dönüştüğünü ifade ederken De Mooij (1998), reklamın kültürel değerlerin taşıyıcısı olarak tüketici güdülerini, yaşam biçimlerini ve ürün seçimlerini şekillendirmede önemli bir güç olduğunu belirtmiş, Pollay (1983) da benzer şekilde reklamın, hem önemli bir iletici hem de belli kültürel değerleri güçlendirici olduğu fikrini savunmuştur (Dahl 2004, s. 1). Reklamın kampanyalarının başarıya ulaşmasında hedef kitlenin sosyo demografik özellikleri, reklamda yaratıcı strateji uygulamalarının hangi kültürel değer ve çekiciliklerle sunulacağı ve kampanyaların etkisini ölçmede özellikle reklamın beğenilip beğenilmemesi konusu reklamcılar için büyük öneme sahiptir.

Tüketiciler, çeşitli medya kanallarından sürekli mesaj bombardımanına maruz kaldıkları için reklama sürekli irite edici, müdahaleci gözüyle bakabilir ve bu şekilde reklam iletişiminden bilinçli kaçınma çabasına girişebilir. Böyle bir durumda reklamcıların reklamlarını duyurmaları da zorlaşmaktadır (Fam ve Waller 2006, s. 42). Ancak reklam beğenildiğinde; markaya yönelik olumlu tutuma (Muehling ve McCann, 1993) ve reklamın içeriğinin hatırlanmasına (Hollis 1995; Ambler ve Burne 1999; Brengman vd. 2001) yol açtığı (Pelsmacker vd. 2004, s. 468) birden fazla maruz kalmayla da (post-exposure) iknanın ve satın almanın (Walker ve Dubitsky 1994) gerçekleşeceği çalışmalarla ortaya konulmuştur (Franzen 2002, s. 262).

1960'larda başlayan reklam beğenilirliği araştırmalarında; izleyicilerin bir reklamı gördükten sonra düşüncelerinin ve hissettiklerinin ne olduğunu, sıfatlar veya ifadeler 
yoluyla tarif etmesi (Aaker ve Bruzzone 1981; Biel ve Bridgewater 1990; Aaker ve Stayman 1990; Greene 1992) istenmiş ya da bir reklama yönelik tutum (Aad) ölçümü yapılmıştır. Bir reklama yönelik tutum çalışmalarının yapısı, duyuşsal ve bilişsel tepkilere ve bir markaya yönelik tutumla $(A b)$ ilişkisine dayanır (Örneğin; Batra ve Ray 1983; Lutz 1985; MacKenzie, Lutz ve Belch 1986; MacKenzie ve Lutz 1989). Reklama yönelik bilişsel tepkilerin incelendiği araştırmada Chung ve Zhao (2003), reklam beğenilirliğinin, reklam mesajına yönelik bilişsel işleme sürecini etkilediği sonucuna ulaşmıştır (Praet 2007, s. 129).

Tüketicinin reklam mesajını sadece biliş ya da salt duygu yoluyla işlediğini ileri süren önemli model ve yaklaşımlar tanımlanmıştır. Bu modellerden biri olan Ayrıntılandırma Olasılığı Modeli (ELM), tüketicilerin mesajı kabullenmesinin ya da reddetmesinin akıl yürütmeyle ve güdüleme süreçleri ile gerçekleştiğini, iknanın da (merkezi ve çevresel olarak gerçekleşen) bilişsel bir süreç olarak değerlendirildiğini savunur (Demirtaş Madran 2012, s. 63-65). Bu model, tutum değişiminde merkez ve çevre sürecinin paralel etkilerini yeterli derecede hesaplayamadığı için eleştirilmektedir. Bilginin merkez ya da çevre durumlarının hangisine ait olduğunun belirlenememesi modelin sınırlıı̆̆ını göstermektedir (Elpeze Ergeç 2004, s. 24-31).

Temelini bilişsel tepki modelinden alan diğer bir model ise Eagly ve Chaiken (1980) tarafından geliştirilen Sezgisel Sistematik Modeldir (HSM). Modelin sistematik sürecinde; hedef, gönderilen mesajı kapsamlı şekilde değerlendirip mesajın sonucuna ilişkin değerlendirmelerde bulunduğunda gerçekleşir. Sezgisel süreçte ise bilginin işlenmesi sınırlıdır. Benzer bilgilerin bellekte depolandığı ve yeni bilgiyle karşılaşıldığında önceki bilgi setinin esas alınarak karar verme sürecinin gerçekleşeceğine işaret eder. Bu model deneysel olarak çok fazla desteklense de reklama yönelik canlanan duyguları görmezden gelmiştir (Demirtaş Madran, 2012, s. 70).

Reklam beğenilirliğini bilişsel ve duyuşsal bileşenlerin çoklu yapısı olarak tanımlayan Alvitt (1987)'in görüşü temel alındığında değinilen reklam çalışmaları ve modelleri, reklam mesajlarına tepkide duygusal sürecin etkisinin zayıf olduğu bilişsel yolu ya da bilişsel tepkiden bağımsız duygusal yolu açıklamışlardır. Ancak tek başına bilişsel ya da duyuşsal boyutun incelenmesinin beğenilirliği açıklamakta yetersiz kaldığı düşünülmektedir.

Reklam beğenilirliği ile ilişkilendirilen bir diğer bir konu ise, reklamda yaratıcı stratejidir. Yaratıcı stratejiyi oluşturan iki unsur: İçerik ve uygulama biçimidir. 'İçerik'; bilgisel (ürün özellikleri ve ürünün faydası) ve ikna edici unsurları içerirken, 'Uygulama biçimleri' (iletişimi sağlayan kişi veya şey, eylem, müzik ve benzeri), mesajın bir bağlam içinde gösterilmesidir. Reklam çalışmalarında yaratıcı strateji uygulama biçimleri, genellikle içerik analizi yardımıyla tanımlanmıştır (Shimp 1976; Stewart ve Furse 1984-1986). $\mathrm{Bu}$ araştırmada ise izleyicilerin reklamda yaratıcı strateji uygulama biçimlerine yönelik tepkileri, odak grup görüşmesi ve soru formu aracılığıyla elde edilmiştir.

Yukarıda reklam beğenilirliğine ilişkin tanımlar, modeller ve araştırmalar incelendiğinde televizyon reklamına yönelik beğenilirliğin bilhassa bilişsel ve duyuşsal yollarla ayrı ayrı açıklandığı görülmüştür. Ayrıca; beğenilirliğin daha çok ikna, hatırlama ve satın alma üzerine etkisinin araştırıldığı çalışmalar literatürde ağılık kazanırken beğeniyi 
oluşturan (demografik, psikografik, kişilik özellikleri, reklama yönelik tutum, markaya yönelik tutum ve yaratıcı strateji gibi) girdilerin çalışmalarda bütüncül olarak değerlendirilmediği ve eksik bırakıldığı tespit edilmiştir.

Televizyon reklamlarına yönelik izleyicilerin beğenisini oluşturan değişkenlerin (girdilerin) belirlendiği ve bu değişkenlerin bir model aracılığı ile gösterildiği herhangi bir araştırmanın yapılmamış olması, bu çalışmanın sorununu oluşturmaktadır.

\section{Yöntem}

Araştırmanın amacına, evren ve örnekleme, modele ve katılımcılara ilişkin verilere bu başlık altında değinilmiştir.

\subsection{Araștırmanın Amacı}

Çalışmada; televizyon reklamına yönelik beğeniyi oluşturan değişkenlerin (girdilerin) belirlenmesi ve her bir değişkenin reklam beğenilirliği üzerine etkisini bir model aracılığı ile göstermek amaçlanmıştır. Bu amaç doğrultusunda aşağıdaki araştırma sorularına yanıt aranmıştır:

1. Demografik değişkenler, reklam beğenilirliğini nasıl etkilemektedir?

2. Psikografik Değişkenler, reklam beğenilirliğini nasıl etkilemektedir?

3. Bir reklama yönelik tutum, reklam beğenilirliğini nasıl etkilemektedir?

4. Bir markaya yönelik tutum, reklam beğenilirliğini nasıl etkilemektedir?

5. Reklamda yaratıcı strateji değişkeni, reklam beğenilirliğini nasıl etkilemektedir?

\section{Reklam Beğenilirliğini Olușturan Değișkenleri Belirlemeye Yönelik Bir Model Önerisi}

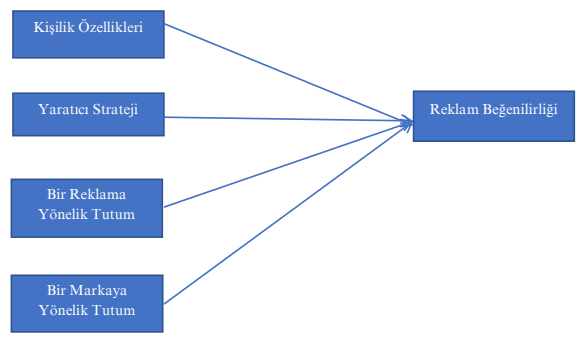

Şekil 1. Reklam Beğenilirliği Modeli İlk Hali

Reklam Beğenilirliği Modelinde yer alan değişkenlerin sayısının ikiden fazla olması çok değişkenli analiz yapılmasını gerektirir. Bu analiz, bir bağımlı değişken ve birden fazla bağımsız değişkenle yapılan çoklu ve lojistik regresyon analizinde olduğu gibi tasarıma göre çeşitlilik gösterir. (Erdoğan 2012, s. 286). Geliştirilen model ile kişilerin demografik değişkenleri, kişilik özellikleri, yaratıcı strateji uygulamaları, bir reklama yönelik tutum ve bir markaya yönelik tutum bağımsız değişkenlerinin, bağımlı değişken olan reklam beğenilirliği üzerine etkisi araştırılmıştır. 


\subsection{Evren ve Örneklem}

Çalışma, nicel yönteme göre dizayn edilmiş olup, Marketing Research: An Applied Approach, Prentice Hall, European Edition adlı kitapta yer alan örneklem hacmi referans alınarak yürütülmüştür (Malhotra ve Birks 2000'den aktaran Gegez 2007, s. 259). Saha çalışması, Antalya il merkezi Kepez ilçesinde yapılımıştır. Antalya Kepez ilçe nüfusu $497.242^{4}$ olup evrenin tamamına ulaşmak mümkün olmadığından tesadüfi olmayan örnekleme yönteminden kolayda örnekleme yöntemi kullanılmıştır. Demografik değişkenler, bu çalışmanın önemli bir değişkeni olduğundan, cinsiyet üzerine bir yığılmayı önlemek amacıyla eşit düzeyde katılım esas alınmış ve 300 kişi ile çalışma yürütülmüştür.

\subsection{Verilerin Toplanması ve Kullanılan Ölçme Aracı}

Araştırmanın nicel verileri; geliştirilen modelde yer alan her bir değişkene ait (kişilerin demografik göstergeleri, kişilik özellikleri, reklama yönelik tutumları, markaya yönelik tutumları, yaratıcı strateji uygulama biçimleri ile beğeniyi tanımlayan sıfatlar) ifadelerden oluşan ölçekler aracılığı ile toplanmıştır. Her bir değişkenin ölçümünde; yabancı kaynaklı ölçeklere ait ifadeler kullanıldığından, İngilizceye hakim bir uzman tarafından çevirisi kontrol edilmiş ayrıca ön test aşamasında anlaşılmayan ifadeler, tekrardan gözden geçirilmiş ve son test bu düzenlemelerin ardından yapılmıştır. Araştırma modelinde yer alan her bir değişkene ait operasyonel tanımlar şöyledir:

Demografik Değişkenler: Demografik; aile büyüklüğü, yaş, cinsiyet, meslek, gelir gibi ekonomik ve sosyal faktörlerin istatistiki olarak sunumudur (Wells vd. 2000, s. 92). Demografik değişkenler; çalışmada yaş, cinsiyet ve eğitim düzeyine ilişkin sorularla ölçülmüştür.

Yaş: Insanlar, yaşamlarının her aşamasında farklı ihtiyaçlar duyar. Reklam mesajlarında da bu yaş grupları hedeflenerek ürün ve hizmetler sunulmaktadır (Wells vd. 2000, s. 97). Çalışmada 18 yaşından 70 ve üstüne kadar farklı yaş gruplarının araştırmaya katııımı sağlanmıştır. Yaş değişkenine ilişkin veri, açık uçlu soru şeklinde soru aracılığı ile toplanmıştır.

Cinsiyet: Reklam kampanyası planlama aşamasında cinsiyeti, temel ve ikincil farklılıklar olarak düşünülmektedir. Temel cinsiyet farklıııları kadın ve erkeğin doğasında olan fiziksel ve psikolojik davranışlardır. İkincil cinsiyet farklılıkları ise bir diğer cinsiyete göre daha iliş̧kili olma eğilimidir (Wells vd. 2000, s. 98-99). Çalışmada, cinsiyet ayrımına gidilmeden kadın ve erkek katılımcıların eşit düzeyde çalışmaya katılımı esas alınmıştır. Bu değişkene ilişkin ölçüm nominal düzeydedir.

Eğitim Düzeyi: Eğitim seviyesi yüksek tüketicilerin; teknik ve bilimsel çekicilikli, bilgi içerikli, fiyat ve ürün kalitesi arasındaki ilişkiyi gösteren reklamları tercih ettikleri çalışmalarla desteklenmiştir (Wells vd. 2000, s. 100). Çalışmada, kişilerin eğitim durumlarının, reklam beğenilirliğine göre farklılık gösterip göstermediği incelenmiştir. Eğitim değişkeni, sıralamalı ölçek düzeyindedir. 
Psikografik Değişkenler: Araştırmalarda psikografik değişkenler, tüketicilerin eylemleri, ilgileri ve düşünceleri olarak incelenmektedir (Dutta 2006, s. 104). Psikografik değişkenler; sağlık bilinci, çevre bilinci, toplumsal ilginlik, güven, fikir liderliği, girişimcilik, fiyat bilinci, ürün bilinci, marka bilinci, moda bilinci, muhafazakarlık, cinsiyet eşitsizliği ve inançlar alt faktörlerinden oluşmaktadır.

Kişilik Özellikleri: Kişilik; bireyleri diğerlerinden ayıran davranış, tutum ve değerler gibi en temel özellikler olup 'bireyin ayırıcı özelliği' şeklinde tanımlanabilir (Aytaç 2009, s. 155). Çalışmada, Kişiliğin Beş Faktörü Modeli (Big Five) esas alınmıştır. Modelde beş faklı kişilik yapısı; dışa dönüklük, duygusal denge, sorumluluk, uyumluluk ve yaşantıya açıklık alt faktörlerinden oluşmaktadır.

Bir Reklama Yönelik Tutum: Edell ve Burke (1987) bir reklama yönelik tutumu, bilişsel ve duyuşsal (affective) bileşenlerle açıklamıştır. Bilişsel unsurlar, reklam niteliklerinin yargısal kısmını oluşturur (örneğin, bilgilendirici olması yönüyle reklamın kendisini tanımlama) duyuşsal unsurlar ise, maruz kalma esnasındaki duygusal (örneğin, eğlenmek/şaşırmak, usanmak, duygulanmak) deneyimlerdir.

Bir Markaya Yönelik Tutum: Bir markaya yönelik tutum, kişilerin reklam uyaranını izledikten sonra o markaya yönelik olumlu ve olumsuz tepki verme eğilimi olarak tanımlanır (Geuens ve Pelsmacker 1998, s. 1).

Yaratıcı Strateji: Yaratıcı strateji, reklamda ne söylendiği (mesaj stratejisi) ile beraber bunun nasıl (uygulama biçimleri) söylendiğini içeren ikili bir yapıya (Wells vd. 2000; Aitken vd. 2003) sahiptir.

Reklam Beğenilirliği: Reklam beğenilirliği, izleyicilerin ihtiyaçları ve davranışları ile uyumlu rasyonel argümanlara kapı açacak duygusal değerlerin kullanımı, mizahi reklamlar, reklamın kodlanması yoluyla izleyicilerin psikografisinin yorumlanıp tam anlamıyla anlaşılması (Kennedy vd. 1999, s. 10) olarak tanımlandığı gibi Nguyen ve arkadaşları (2013, s. 32) tarafından da tüketicilerin olumlu tutumları, marka tercihleri ve duygularıyla ilişkilendirmiştir. Çalışmada reklam beğenilirliği sıfatları için 7’li semantik farklılık ölçeği kullanılmıştır.

Soru formunun ilk bölümünde; deneklere demografik ve kişilik özelliklerine ilişkin sorular, ikinci bölümünde ise "Tadım Türkiye'nin En Büyük Sosyal Ağ” reklamı izlettirildikten sonra bir reklama yönelik tutum, yaratıcı strateji ve reklam beğenilirliği değişkenlerini ölçmeye yönelik ifadeler yer almaktadır. Araştırmanın bu reklam üzerinden yürütülmesinin gerekçeleri şunlardır:

- Reklam ajanslarının ve çalışanlarının özgün çalışmalarını değerlendirmeye yönelik 2015 yılında düzenlenen 27. Kristal Elma Yaratıcılık Festivali'nde çikolata, şekerleme ve çerez alt kategorisinde Kristal Elma ödülü alması,

- Bu çalışma; kadın ve erkek katılımcılara yönelik yürütüldüğünden, reklam filminde cinsiyet farkı gözetmeyen ve bütün kesimler tarafından kolay ulaşılabilir ve satın alınabilir hızlı tüketim ürünleri kategorisinde yer alan bir marka olması,

- Reklam filminde teknolojinin gelişimi ile iletişim kanallarında yaşanan değişim eğlenceli bir şekilde sunulurken, markanın aynı kalması ve geçmişten 
günümüze vurgusu ile farklı yaş gruplarını hedeflemesi,

- Bilgisel (iddiasının olması) ve dönüşümsel mesaj stratejilerinin (marka imajı, ve psikolojik çekicilikle güdüleme, sıradan kişilerin kullanılması ile yaşamdan bir kesit sunması) etkili sahne, ışık ve renk gibi uygulama biçimleri ile desteklenmesi gibi etkenler göz önünde bulundurulmuştur.

Reklam beğenilirliği değişkeninin ölçümünde çeşitli sıfatlar kullanılmıştır. Soru formunda yer alan reklam beğenilirliğini tanımlayıcı sıfatların kullanıldığı çalışmalar (Leavitt 1970; Wells, Leavitt ve McConville 1971; Schlinger 1979; Aaker ve Bruzzone 1985; Moldovan 1985; Aaker ve Stayman 1990; Biel ve Bridgewater 1990; Haley ve Baldinger 1991; Greene 1992; Du Plessis 1994; Dubitsky ve Walker 1994; Leather, McKechnie ve Amirkhanian 1994; DeCock ve DePelsmacker 2000) incelenmiş aynı anlama gelenler birleştirilmiş ayrıca odak grup görüşmesinden elde edilen verilerin de ilave edilmesi ile beğeniye yönelik sıfat ifadeleri zenginleştirilmiştir. Beğeni değişkeni, semantik farklıık ölçeği ile ölçülmüştür.

Reklam beğenisinin ölçümüne yönelik sıfatların oluşturulmasında ayrıca araştırmacının konuya ilişkin yaptığı odak grup görüşme verileri de belirleyici olmuştur. Ölçekteki ifadeler ile bu veriler karşılaştırılmış, benzer olanlar elenmiş sadece 'ilgi uyandırıyor', 'kültürel değerlerle uyumlu' sıfatları eklenerek soru formuna son hali verilmiştir.

Bir reklama yönelik tutumun, reklam etkililiği ve duygusal tepkiler yoluyla dikkati artırdığı (Mitchell ve Olson 1981), negatif etkilerin zayıflayarak pozitif duyguların uyarıldığı ve reklam beğenilirliğinin markaya yönelik olumlu tutum geliştirmeye öncülük ettiği çeşitli araştırmacılar tarafından ortaya konulmuştur (Geuens ve Pelsmacker 1998, s. 1). Geuens ve Pelsmacker (1998) tarafından popüler aile dergilerinden seçilen 43 alkolik içecek reklamı; mizah, erotizm, samimi kategorilerine ayrılmış ve katılımcılara reklamın hangi markaya ait olduğunu tanımlamaları, duygusal ve bilişsel hisleri, bir reklama ve bir markaya yönelik tutumları ile satın alma niyetleri sorulmuştur. Çalışmada bu ölçeğe ait bir reklama ve bir markaya yönelik tutum ifadeleri 'Kesinlikle Katılmıyorum' ve 'Kesinlikle 'Katılıyorum' beşli Likert ölçeği ile ölçülmüştür. 'Bu reklamın bilgilendirici olduğunu düşünürüm' ifadesi araştırmacının konu ile ilgili yaptığı odak grup görüşmesinden elde ettiği bir diğer veri olup soru formuna ilave edilmesi ile ifadeler zenginleştirilmiştir.

Modelde yer alan bir diğer değişken kişilik özelliklerinin ölçümüne ait ifadeler, Costa ve McCrae (1992)'nin 'Four Ways Five Factors are Basic' makalesinde yer alan Beş Büyük Faktör Kişilik Envanterine (Big Five) dayanmaktadır. Bu faktörler; Dışa dönüklük (Extraversion), Uyumluluk (Agreeableness), Sorumluluk (Conscientiousness), Duygusal Denge (Emotional Stability) ve Yeniliklere açıklıktır (Openness to New Experiences). Beş büyük faktör ve on ifadeden oluşan kişilik ölçeği; Gosling, Rentfrow ve Swann'ın (2003) Journal of Research in Personality dergisinde yer alan 'A Very Brief Measure Of The Big Five Personality Domains' başlıklı çalışma referans alınarak hazırlanmış ve ifadeler 'Kesinlikle Katılmıyorum'- 'Kesinlikle Katılıyorum' aralığına sahip beşli Likert ile ölçülmüştür.

Yaratıcı strateji değişkeninin ölçümüne ilişkin ifade seti, Manrai ve arkadaşları (1992) 
tarafından Journal of Business Research'de yer alan 'Advertising Appeal And Tone: Implications For Creative Strategy In Television Commercials' makalesi referans alınarak hazırlanmıştır. Araştırmacılar tarafından yaratıcı stratejiye; Eylem, iddia, renk, ses şiddeti, müzik, hız, kişiler, görüntü, hikâyenin geçtiği yer, özel ses ve özel video efektler, konu ve sözlere ilişkin ifadeler, Kesinlikle Katılmıyorum'- 'Kesinlikle Katılıyorum' aralığına sahip beşli Likert ile ölçülmüştür.

\subsubsection{0̈n (Pilot) çalıșma}

Her bir ölçme aracında yer alan ifadelerin anlaşılırlığını ve geliştirilen modelin işlerliğini test etmek amacı ile Antalya ili Kepez ilçesinde ikamet eden, farklı yaş aralığına sahip 30'u kadın 30'u erkek 60 kişiye yönelik ön test/pilot çalışma yapılmıştır. Bu araştırmadan elde edilen veriler, SPSS 22 İstatistik programına yüklenmiş ve analizler yapılmıştır. Pilot çalışmasının yapıldığı reklam beğeni değişkenleri Şekil 2'de yer almaktadır.

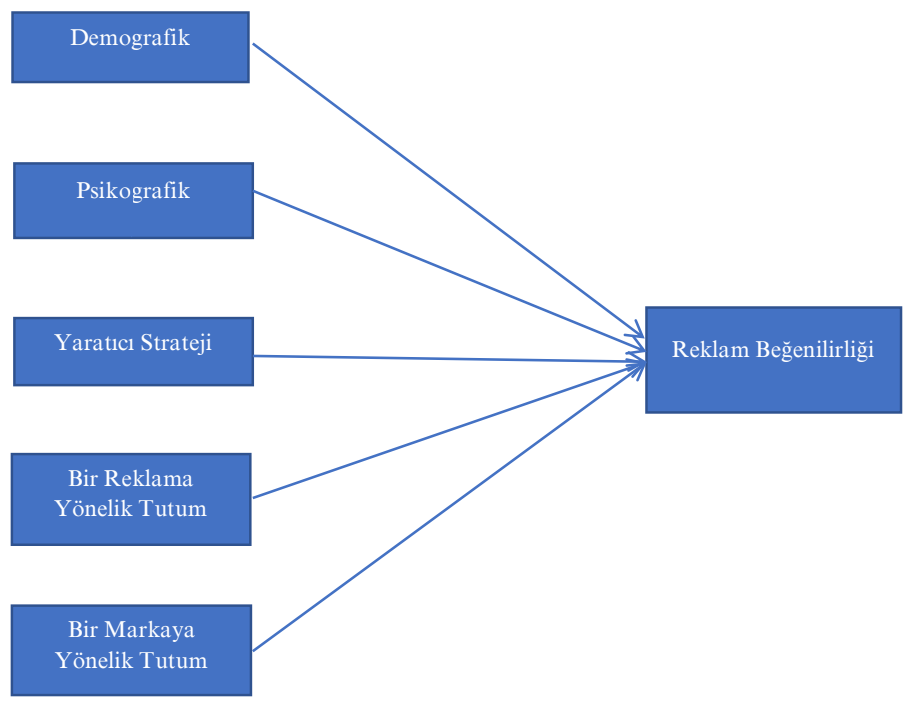

Şekil 2. Reklam Beğenilirliğini Etkileyen Değişkenler

Yukarıda Şekil 2 'de yer alan 'reklam beğenilirliğini' tanımlayan sıfatlar 1 ile 7 arasında kodlanarak (1=En Düşük, 7=En Yüksek) Semantik Farklılık Ölçeği ile ölçülmüştür. 23 reklam beğeni sıfatı için yapılan güvenilirlik analizi sonucunda Cronbach's Alpha değeri: 0.94 olarak bulunmuştur.

Modelde yer alan diğer değişkenlere ait ifadelerin güvenilirlik analizi yapıldığında, Bir reklama yönelik tutum değişkeni ifadelerinin güvenilirlik skoru olan Cronbach's Alpha katsayısı: 0,63'dür. Durmuş ve arkadaşlarına (2011) göre soru sayısı az olduğunda 0,60 değeri ve üstü kabul edilebilmektedir. Bir markaya yönelik tutum ölçümünün Cronbach's Alpha katsayısı: 0,86 ve yaratıcı strateji değişkenin Cronbach's Alpha katsayısı: 0,91 olduğu bulunmuştur. Bu değişkenlerin her birinin ortalaması (reklama yönelik tutum, markaya yönelik tutum, yaratıcı strateji) alınmış ve reklam beğenilirliğini açıklamada istatistiki olarak anlamlı olup olmadığını test etmek için regresyon analizi yapılmıştır. 
Regresyon analizi sonucunda reklama yönelik tutumun $\left(R=0.47, R^{2}=0.22, F=16.67\right.$, $\mathrm{p}<.05)$, markaya yönelik tutumun $\left(\mathrm{R}=0.43, \mathrm{R}^{2}=0.18, \mathrm{~F}=13.40, \mathrm{p}<.05\right)$ ve yaratıcı stratejinin $\left(R=0.47, R^{2}=0.22, F=17.12, p<.05\right)$, reklam beğenilirliğini açıklamada istatistiki olarak anlamlı olduğu sonucuna ulaşıımıştır.

Modelde yer alan demografik değişkenlerin reklam beğeni sıfatlarını açıklamada anlamlı olup olmadığını ortaya koymak amacı ile regresyon analizi yapılmıştır. Regresyon analizinde cinsiyet, medeni durum ve eğitim durumu için kukla değişkenler oluşturulmuş ve reklam beğeni sıfatlarını açıklamada anlamlı bir değere sahip olup olmadığı test edilmiştir. Analiz sonucunda reklam beğeni sıfatlarını açıklamada; cinsiyet $\left(R=0.13, R^{2}=0.0, F=0.00, p>.05\right)$, medeni durum $\left(R=0.18, R^{2}=0.03, F=2.02\right.$, $p>.16)$ ve eğitim durumu $\left(R=0.23, R^{2}=0.05, F=3.32, p>.07\right)$ için anlamlı bir sonuç elde edilememiştir.

Çalışmanın amacı doğrultusunda reklam beğenilirliğini etkilediği düşünülen bir diğer değişken Psikografi değişkenine ait ifadeler; Dutta Bergman (2006) tarafından Journal of Advertising Research'de yer alan 'The Demographic And Psychographic Antecedents Of Attitude Toward Advertising' adlı makale referans alınarak hazırlanmıştır. Bu makalede psikografik değişkenler; sağlık bilinci, çevre bilinci, toplumsal ilginlik, güven, fikir liderliği, girişimcilik, fiyat bilinci, ürün bilinci, marka bilinci, moda bilinci, muhafazakârlık, cinsiyet eşitsizliği ve inançlar faktörleri ile incelenmiştir. Psikografik değişkenlere ait ifadelerin Cronbach's Alpha katsayısı: 0,81'dir. Yüksek güvenilirlik skoruna sahip psikografik değişkenin, beğeniyi açıklamada istatistiki olarak anlamlı olup olmadığını test etmek amacı ile bu değişkene ait her bir faktörün ortalaması alınmış ve reklam beğeni sıfatlarının ortalaması ile Regresyon analizine sokulmuştur. Araştırma Sorusu 2'yi yanıtlamak için analiz öncesinde 'Fiyat Bilinci Boyutu' altında yer alan 'Üreticinin ikramını gönderirim/iade ederim' ve 'Güven Boyutu' altında yer alan 'Yüksek kademedeki bir göreve dürüst insanlar seçilmez', 'Büyük şirketlerin çoğu sadece kendi çıkarını düşünür' ifadeleri ters kodlanmıştır. Yapılan regresyon analizi sonucunda psikografik değişkene ait faktörlerden sadece çevre bilincinin, reklam beğeni sıfatlarını açıklamada anlamlı bir değere $\left(R=0.35, R^{2}=0.12, F=8.55, p<.05\right)$ sahip olduğu, diğer faktörlerin anlamlı bir sonuç göstermediği bulunmuştur. Bu nedenle psikografi değişkeninin modelden çıkartılması uygun görülmüştür.

\section{Bulgular ve Yorum}

Araştırmanın pilot aşamasında, reklam beğeni değişkenleri arasında gösterilen psikografi değişkeninin işlemediği tespit edilmiştir. Bu değişken modelden çıkarılarak Şekil 1 'de yer alan 'Kişilik Özellikleri' değişkeninin eklenmesi ile reklam beğenilirliği modelinin ilk hali geliştirilmiştir. Modele eklenen bu yeni değişkenle birlikte modelde yer alan diğer değişkenlere ait toplanan verilerin, istatiksel çözümlemeleri yapılmış ve yorumlanmıştır. Modelde yer alan her bir değişkene ait bulgular alt başlıklar halinde incelenmiştir.

\subsection{Beğeni Sıfatlarının Ortalaması}

Reklam beğenilirliğini oluşturan değişkenleri belirlemeye yönelik geliştirilen modelde; 
beğeni, semantik ölçekte hazırlanmış sıfatlar aracılığı ile ölçülmüştür. 1 en düşük, 7 en yüksek olarak kodlanmıştır. Soru formunda yer alan 23 beğeni sıfatından sadece 'Abartılı' ifadesi ters kodlanmıştır. Beğeni sıfatlarına ait sıfatların Cronbach's Alpha değeri: 0,93 olup Durmuş ve diğerlerine (2011) göre 0,70 ve üstü bir ölçek güvenilir kabul edilir. Katılımcıların beğeniyi tanımlamada kullandıkları 23 sıfatın ortalama değeri 5,75'dir. Bu değere göre katılımcılar reklamı beğendiklerini belirtmişıler ve beğeniyi en çok ( 6 ve üstü ortalamaya sahip) şu sıfatlarla değerlendirmişlerdir: 'Eğlenceli', 'Amaca uygun', 'Anlaşılır', Gerçek hayattanmış gibi', 'Sinirlendirmiyor', 'Saçmalamıyor', 'Abartılı değil', 'Samimi' ve 'Başarılı'. Ayrıca katılımcılar beğendikleri (5-5,9 arası) reklamı 'Yaratıcı', 'Orijinal', 'Etkili', 'Bilgi içeriyor', 'Akılda kalıcı', 'Ilginç', 'Haz verici', 'Empatik', 'Akıcı', 'Ilgi uyandırıcı' ve 'Kültürel değerlerle uyumlu' olarak değerlendirmişlerdir. Katılımcılar, reklamın 'Yeni' $(4,2)$ ve 'Ikna edici' olduğu $(4,5)$ konusunda ise kararsız bir yaklaşım sergilemişlerdir.

\subsection{Demografik Verilere Ilișkin Frekans ve Regresyon Analizi}

Çalışmada demografik veriler; cinsiyet, eğitim ve yaş ile ölçülmüştür. Tablo 1 'de deneklerin demografik verileri yer almaktadır.

Tablo 1. Demografik Göstergeler

\begin{tabular}{|c|c|c|}
\hline Yaş Aralı̆̆ı & Sayı & Geçerli Yüzde \\
\hline $\mathbf{1 8 - 2 2}$ & 47 & 15,7 \\
\hline $\mathbf{2 3 - 2 7}$ & 122 & 40,7 \\
\hline $\mathbf{2 8 - 3 2}$ & 45 & 15,0 \\
\hline $\mathbf{3 3 - 3 7}$ & 37 & 12,3 \\
\hline $\mathbf{3 8 - 4 2}$ & 13 & 4,3 \\
\hline $\mathbf{4 3 +}$ & 36 & 12,0 \\
\hline Toplam & 300 & 100 \\
\hline Eğitim Durumu & Sayı & 18,3 \\
\hline ilköğretim & 55 & 48,3 \\
\hline Lise & 145 & 10,7 \\
\hline Ön Lisans & 32 & 22,0 \\
\hline Lisans & 66 & 0,7 \\
\hline Lisansüstü & 2 & 100 \\
\hline Toplam & 300 & \\
\hline
\end{tabular}


Katılımcıların yaş ortalaması 29,93 olup yaş aralığı 23 ile 27 arası olanlar \% 40,7 ile en fazla yüzdeye sahiptir. 18 ile 22 yaş aralığında olanlar \%15,7’lik bir yüzdeye, 28 ile 32 yaş aralığında olanlar \% 15'lik bir değere, 33 ile 37 yaş aralığına sahip olanlar \% 12,3'lük bir değere, 43 ve üstü olanlar \% 12'lik bir yüzdeye ve 38 ile 42 yaş aralığında olanlar da \% 4,3 ile en düşük değere sahiptir. Eğitim durumu bakımından liseyi bitirenler \% 48,3 ile en yüksek yüzdeye sahip olup bu değeri sırasıyla lisans (\%22), ilköğretim $(\% 18,3)$ ve ön lisans $(\% 10,7)$ izlemektedir.

Katılımcıların demografik verilerinin reklam beğenilirliğini açıklamada istatistiki olarak anlamlı olup olmadığını belirlemek amacıyla regresyon analizi yapılmıştır. Cinsiyet ve eğitim durumu değişkeni kategorik bir ölçüm olduğundan bağımsız değişkenlerin regresyon analizinde kullanılabilmesi için kukla değişkenlere dönüştürülmesi gerekmektedir (Durmuş 2011, s. 176). Kukla değişkeleri kodlama sürecinde, her bir kategorik değişkenden bir kategori veya nitelik referans grubu olarak (görmezden gelinen grup her zaman 0 değerini alır) seçilmektedir (Cohen vd. 2003'den aktaran Suher ve İspir 2010, s. 17). Kukla (dummy) değişkenlerden her biri metrik olmayan bağımsız değişkenlerin bir kategorisini temsil eder ve "k" sayısındaki kategoriye sahip herhangi metrik olamayan bir değişken "k-1" sayısında bir kukla değişken tarafından temsil edilebilir (Hair vd. 2009'dan aktaran Suher ve İspir 2010, s. 17). Çalışmada cinsiyet değişkeni için 'kadın' olma durumu ve eğitim durumu için de frekansı en yüksek ifade 'lise' ve '23-27 yaş' aralığı 1 olarak kodlanmıştır.

Cinsiyetin, yaşın ve eğitim durumunun reklam beğenilirliğini açıklamada anlamlıık düzeyi için ANOVA analizi yapılmıştır. F değeri 0,63 ve $p$ değeri (Sig.) 0,979 değerine sahiptir. Bu değerlere göre Araştırma Sorusu 1 için, beğeniyi tahmin etmede demografik verilerin istatistiksel olarak anlamlı olmadığı sonucuna ulaşılmıştır. Tablo 2 incelendiğinde her bir değişkenin p (Sig) değerinin istatistiki olarak anlamlı olmadığı görülmektedir.

Tablo 2. Demografik Değişkenler Regresyon Analizi

\begin{tabular}{|c|c|c|c|c|c|}
\hline Model & \multicolumn{2}{|c|}{$\begin{array}{c}\text { Standardize Edilmemiş } \\
\text { Katsayılar }\end{array}$} & $\begin{array}{c}\text { Standardize Edilmiş } \\
\text { Katsayılar }\end{array}$ & \multirow{2}{*}{ T } & Sig \\
\hline & B & Std. Hata & Beta &, 029 &, 000 \\
\hline Sabit & 130,213 & 5,202 & &, 027 &, 645 \\
\hline Cinsiyet (kukla) & 1,118 & 2,455 &, 027 &,-064 &, 949 \\
\hline Eğitim (kukla) & $-0,72$ & 1,117 &,- 004 &, 449 &, 654 \\
\hline Yaş &, 060 &, 134 &, 027 & & \\
\hline
\end{tabular}

Bağımlı Değişken: Beğeni

Katsayı Tablosuna göre beğeniyi açıklamada cinsiyet ( $p=0,02, p>, 05)$, yaş $(p=-0,06$, $p>, 05)$ ve eğitim durumu $(p=0,02, p>, 05)$ anlamlı bir katkı sağlamadığından demografik değişkenin modelden çıkartılması uygun görülmüştür. 


\subsection{Kișilik Özellikleri Güvenilirlik Analizi}

Reklam beğenilirliği modelinde kişilik özelliklerini belirlemeye yönelik kullanılan ölçekte 10 ifade yer almaktadır. Ölçekte yer alan 'Çekingen ve sessiz biriyimdir', 'Eleştiriciyim ve kavgacıyımdır', 'Düzensiz, dağınık ve dikkatsizimdir', 'Endişeli ve kolay üzülen bir kişiyimdir', 'Gelenekçiyim ve yaratıcı değilimdir' ifadeleri analiz öncesi ters kodlanmıştır. Ters kodlama sonrası Cronbach's Alpha değeri ise 0,34'dir. Durmuş'a göre (2011) soru sayısı az olduğunda 0,60 ve üstü kabul edilebilir olup ters kodlama öncesi ve sonrası yapılan güvenilirlik analizi kabul edilebilir oranlar arasında yer almadığından kişilik ölçeğine ilişkin 10 ifade modelden çıkarılmıştır.

\subsection{Tutum Ifadelerine ait Güvenilirlik Analizi ve Ortalamalar}

Reklam beğenilirliği modelinde yer alan bir reklama yönelik tutum ölçeği 6 ifadeden oluşmaktadır. Bu ifadelerin Cronbach's Alpha değeri: 0,68 olup Durmuş ve arkadaşlarına (2011) göre soru sayısı az olduğunda 0,60 değeri ve üstü kabul edilebilmektedir.

Reklama yönelik tutum ifadelerine katılımcıların verdikleri yanıtların genel ortalaması 3,8 olup katılımcılar 'Tadım' markasının reklamını daha çok ilginç $(4,2)$, çekici $(4,2)$ ve inandırıcı $(4,1)$ olarak değerlendirmişlerdir. Ayrıca katılımcılar, 'Kolay unutulacağını düşünürüm' $(3,1)$, 'Bu reklamın etkili olmadığını düşünürüm' $(3,2)$, 'Bu reklamın bilgilendirici olduğunu düşünürüm' ifadelerine yönelik kararsız bir tutum sergilemişlerdir. Markaya yönelik tutum ifadelerinin Cronbach's Alpha değeri: 0,88 olup bu değer gayet yüksek bir skordur.

Markaya yönelik tutum ifadelerinin genel ortalaması 3,6 olup katılımcılar Tadım markasını, ortalaması en yüksek değere sahip $(4,1$ ile) olan 'liyi bir marka olduğunu düşünürüm' ifadesi ile değerlendirmiş ancak markayı başkalarına tavsiye etmede $(3,1)$ kararsız bir tutum takınmışlardır. Katılımcıların ‘Reklamı yapılan markayı beğenirim' ve 'Bu markaya yönelik duygularım olumludur' ifadesine verdikleri yanıtların ortalaması: 3,8 olup markayı beğenmede bir kararsızlık yaşandığı görülürken, reklamı beğenme skorunun 5,75 gibi bir ortalamaya sahip olması, markanın çok beğenilmese de reklamın beğenilebileceğini ortaya koyması açısından önemlidir. Yaratıcı strateji unsurlarına ait ifadelerin Cronbach's Alpha değeri: 0,92 olup bu değer gayet yüksektir.

Reklamda yaratıcı strateji unsurlarına katılımcıların verdikleri yanıtların ortalaması 4,1 olup en yüksek skora sahip iki değer: Reklamın hikayesi ve reklamda kullanılan ifadeler olup bu iki ifade aynı $(4,5)$ yüklenmiştir. 4 ve üstü ortalamaya sahip diğer ifadeler ise 'Kişiler', 'Görüntü seçimleri', 'Yaratıcı', 'Video efektleri', 'Renk', 'Müzik' ve 'Ses efektleridir.' Katılımcılar reklamda bu özelliklerin etkili kullanıldığını düşünürken 'Reklamda aksiyon olduğunu düşünürüm' $(3,2)$, ifadesine yönelik kararsız bir tutum takınmışlar ve aksiyon ifadesini sinema filmlerindeki aksiyon gibi değerlendirdiklerini ifade etmişler ve bu nedenle Tadım reklamında aksiyon olup olmadığı konusunda çekinceli bir tutum sergilemişlerdir. Ayrıca katılımcılar, reklamın 'Vaadi ' $(3,5)$ ve 'Hız' $(3,9)$ unsurları konusunda da kararsız kaldıklarını belirtmişlerdir. 


\subsection{Değișkenler arası ilișkilerin test edilmesi}

Reklam beğenilirliği modelinde yer alan demografik verilerin beğeniyi açıklayıp açıklamadığını araştırmak için Regresyon analizi yapılmış ancak beğeniyi yordamada demografik verilerin istatistiki olarak anlamlı olmadığı sonucuna ulaşılmıştır. Ayrıca modelde yer alan kişilik özellikleri değişkenine ilişkin ölçeğin güvenilirlik skoru kabul sınırının altında kaldığından, bu ölçeğe ait ifadeler modelden çıkartılmıştır. Şekil 3'de Reklam Beğenilirliği Modelinde yer alan (reklama yönelik tutum, markaya yönelik tutum ve yaratıcı strateji) değişkenlere ait ifadelerin güvenilirlik analizi yapılmış ve bu değişkenlerinin beğeniyi açıklamada anlamlı bir yordayıcı olup olmadığını belirlemek için Hiyerarşik Regresyon Analizinden faydalanılmıştır.

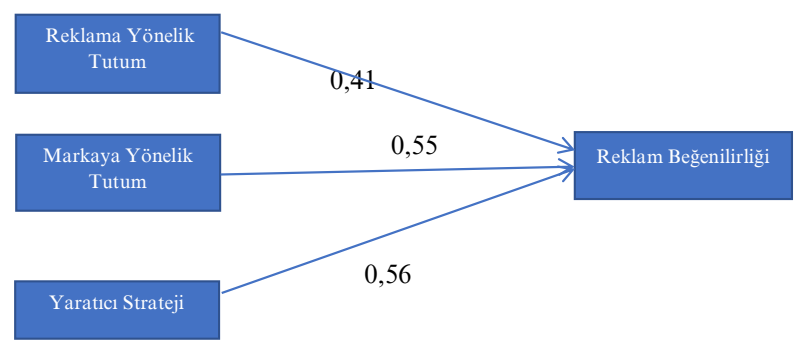

Şekil 3. Reklam Beğenilirliği Modeli

Şekil 3'de gösterilen reklam beğenilirliği modelini test etmede kullanılan Hiyerarşik regresyon analizinde, bağımlı değişkeni en iyi açıklayan modeli belirlemek için bağımsız değişkenler regresyon eşitliğine belirli bir sırada tek tek sokulur (Keith 2005'den aktaran Suher ve İspir 2010, s. 6). Yordayıcı değişkenler (reklama yönelik tutum, markaya yönelik tutum, yaratıcı strateji) araştırmacının belirlediği sıralama doğrultusunda analize alınır ve her bir değişken, bağımlı değişkene (beğeni) ilişkin varyansa olan katkıları bakımından değerlendirilir (Büyüköztürk 2010, s. 100). Bu çalışmada hiyerarşik sıralama için açıklayıcı değişkenler şu şekildedir; reklama yönelik tutum, markaya yönelik tutum ve yaratıcı strateji. Böyle bir sıralama ile analiz yapılmasının gerekçeleri şunlardır:

- Bu sıralamanın belirlenmesinde kişilik özelliklerinin güvenilirlik analizi skorunun kabul sınırının altında kalması ve demografik değişkenlerin kontrol değişkeni olarak hiyerarşik regresyona dahil edilmesi

- Alan yazında reklama yönelik tepkinin markaya yönelik tutuma dönüşebileceği yönünde araştırma bulgularının (Batra ve Ray 1986; Burke ve Edell 1989; Edell ve Burke 1987; Gardner 1985; Goldberg ve Gorn 1987; Homer 1990; MacKenzie, Lutz ve Belch 1986; Mitchell ve Olson 1981; Shimp 1981) varlığı etkili olmuştur. 
Tablo 3. Açıklayıcı Değişkenler ve Kontrol Değişkenlerinin Bağımlı Değişken (Beğeni) Üzerindeki Etkisini Test Eden Aşamalı Regresyon Analizi

\begin{tabular}{|c|c|c|c|c|c|c|c|c|}
\hline \multicolumn{7}{|c|}{ Standardize Edilmiş Beta Değerleri } \\
\hline & N & Model 1 & Model 2 & Model 3 & Model 4 & Model 5 & Model 6 \\
\hline Kontrol Değişkeni & \multicolumn{7}{|c|}{ M. } \\
\hline Kadın ve Erkek & 300 &, 022 &,- 039 &, 025 &, 011 &,- 014 & \\
\hline Yaş & 300 &, 001 &, 029 &, 016 &,- 058 &, 011 & \\
\hline Eğitim Durumu & 300 &,- 011 &, 038 &,- 016 &,- 011 &,- 028 & \\
\hline Bağımsız Değişken & & & & & & \\
\hline $\begin{array}{c}\text { Reklama Yönelik } \\
\text { Tutum }\end{array}$ & 6 & &, $646^{*}$ & &, $303^{*}$ &, $307^{*}$ \\
\hline $\begin{array}{c}\text { Markaya Yönelik } \\
\text { Tutum }\end{array}$ & 4 & & &, $234^{*}$ & &, 030 & \\
\hline Yaratıcı Strateji & 13 & & & &, $754^{*}$ &, $571^{*}$ &, $573^{*}$ \\
\hline F & &, 063 & 51,351 & 4,304 & 96,370 & 82,420 & 248,280 \\
\hline R & &, 001 &, 410 &, 055 &, 566 &, 628 &, 626 \\
\hline VIF & & $1,0-1,2$ & $1,0-1,2$ & $1,5-1,3$ & $1,0-1,3$ & $1,0-1,6$ & $1,0-1,6$ \\
\hline
\end{tabular}

*p (Sig) değeri 0,05 (\% 95) düzeyinde anlamlıdır

Tablo 3'e göre Hiyerarşik regresyon analizinde az sayıdaki bağımsız değişkenle bağımlı değişkenin varyansını en iyi açıklayan, yordayan modelin tespit edilebilmesi ve modele fazla katkısı olmayan değişkenlerin elemine edilmesi amacıyla aşamalı (stepwise) regresyon analizi tercih edilmiştir (Okan vd., 2016: s. 498).

Regresyon analizine başlamadan önce bağımsız değişkenler arasında çoklu bağıntı (multicollinearity) sorunu olup olmadığının kontrolü için ise Varyans Artış Faktörleri (VIF) değerlerinin 10'dan küçük olup olmadığı kontrol edilmiş ve bağımsız değişkenler arasında (en küçük: 1,0 ile en yüksek: 1,6 arasında) çoklu doğrusal bağlantı sorunu (multicollinearity) olmadığı sonucuna ulaşılmıştır.

Açıklayıcı değişkenler ve kontrol değişkenlerinin bağımlı değişken (beğeni) üzerindeki etkisini test eden aşamalı regresyon analizi Tablo. 3'de görüldüğü üzere 6 aşamalı bir model kurularak analiz edilmiştir.

Aşamalı regresyonun ilk aşaması olan Model 1'de bağımsız değişkenler (reklama yönelik tutum, markaya yönelik tutum ve yaratıcı strateji) modelin dışında tutularak sadece kontrol değişkenleri (cinsiyet, yaş, eğitim durumu) ile analiz yapılmış ve bu değişkenlere ait beta katsayıları ve anlamlılık katsayısı (cinsiyet: $\beta=, 022, p>, 709$ yaş: $\beta=, 001 p>, 990$ eğitim durumu: $\beta=-, 011, p>, 856)$ incelendiğinde beğeniyi yordamada 
anlamlı olmadıkları görülmüştür.

İkinci aşamada; Model 2'ye kontrol değişkenleri ile birlikte bağımsız değişkenlerden (açıklayıcı değişken) reklama yönelik tutum eklenerek regresyon analizi yapılmıştır. Araştırma sorusu 3'ü cevaplamak için yapılan analizde; kontrol değişkenleri (cinsiyet: $\beta=-, 039 p>, 398$ yaş: $\beta=, 029 p>, 332$; eğitim durumu: $\beta=, 038 p>, 419$ ) beğeniyi açıklamada anlamlı değilken, 'reklama yönelik tutum' $(\beta=-, 646 \quad p<, 00)$ bağımsız değişkeninin, beğeniyi açıklamada istatistiki olarak anlamlı olduğu bulunmuştur. Model 2'de yer alan değişkenler, beğeniyi \% $41\left(R^{2}\right)$ oranında açıklamaktadır.

Üçüncü aşamada; Araştırma Sorusu 4'ü yanıtlamak için Model 3'de kontrol değişkenleri (cinsiyet, yaş, eğitim durumu) ile birlikte açıklayıcı değişkenlerden markaya yönelik tutumun bir arada beğeniyi yordamada anlamlı olup olmadığı kontrol edilmiştir. Bu modelde, Model 2'de yer alan reklama yönelik tutum değişkeni elemine edilmiş ve markaya yönelik tutum değişkeni tek başına kontrol değişkenleri (cinsiyet: $\beta=-, 014$, $p>, 70$; yaş: $\beta=-, 028, p>, 45$; eğitim durumu: $\beta=, 011, p>76$ ) ile analiz edilmiştir. Kontrol değişkenleri, istatistiki olarak anlamlı olmamasına rağmen 'markaya yönelik tutum' bağımsız değişkeni $(\beta=, 234 p<, 00)$, beğeninin anlamlı bir yordayıcısıdır. Model 3 beğeniyi açıklamada \% $55\left(\mathrm{R}^{2}\right)$ ile Model 2 'den daha yüksek yüzdeye sahiptir.

Dördüncü aşamada Model 4'de kontrol değişkenleri (cinsiyet, yaş, eğitim durumu) ile birlikte açıklayıcı değişkenlerden yaratıcı strateji değişkeninin beğeniyi yordamada anlamlı olup olmadığı kontrol edilmiştir. Araştırma Sorusu 5 için bu modelde, Model 2'de yer alan reklama yönelik tutum ve Model 3'de yer alan markaya yönelik tutum bağımsız değişkenleri dışarıda bırakılmış ve yaratıcı strateji değişkeni tek başına kontrol değişkenleri (cinsiyet: $\beta=, 011, p>768$, yaş: $\beta=-, 058, p>, 152$ eğitim durumu: $\beta=-$ $, 011, p>, 787)$ ile analize sokulmuştur. Kontrol değişkenleri, istatistiki olarak anlamlı olmamasına rağmen 'yaratıcı strateji' değişkeni $(\beta=, 754 p<, 00)$ beğeninin anlamlı bir yordayıcısıdır. Model 4 beğeniyi açıklama yüzdesi ise \% $56\left(R^{2}\right)$ 'dır.

Beşinci aşamada Model 5'de ise kontrol değişkenleri (cinsiyet, yaş, eğitim durumu) ile birlikte açıklayıcı değişkenlerin bütününün (reklama yönelik tutum, markaya yönelik tutum ve yaratıcı strateji) beğeniyi yordamada anlamlı olup olmadığı kontrol edilmiştir. Model 5'de kontrol değişkenleri (cinsiyet: $\beta=,-014 p>702$, yaş: $\beta=-, 028 p>, 455$ eğitim durumu: $\beta=-, 011, p>, 761)$ ve 'markaya yönelik tutum' değişkeni $(\beta=, 030 p>, 420)$ istatistiki olarak beğeniyi açıklamada anlamlı olmamasına rağmen 'reklama yönelik tutum' $(\beta=, 303 p<, 00)$ ve 'yaratıcı strateji' değişkeni $(\beta=, 571 p<, 00)$ beğeninin anlamlı bir yordayıcısı olup, Model 5 beğeniyi \% $63\left(R^{2}\right)$ oranında açıklamaktadır.

Model 6'da Model 5'de yer alan ve beğeniyi yordamada anlamlı olmayan kontrol değişkenleri ve açıklayıcı değişkenlerden marka tutumu elemine edilerek modele katkısı olan iki değişkenle: 'Reklama yönelik tutum' ve 'yaratıcı strateji' ile analiz tekrarlanmıştır. Bu şekilde kurulan modelin beğeniyi açıklamada diğer iki modele göre yüzdesinde bir değişme olmamış ve reklama yönelik tutum $(\beta=, 307 p<, 00)$ ile yaratıcı strateji $(\beta=, 573 p<, 00)$ değişkeni birlikte beğeniyi \% $63\left(R^{2}\right)$ oranında açıklamıştır. 


\section{Sonuç ve Tartıșma}

Çalışmada, televizyon reklamına yönelik izleyicilerin beğenisini (LA) oluşturan değişkenler, bir model önerisi ile açıklanmıştır. Bu bölümde; modelin geliştirilme sürecindeki aşamalar, beğeni literatüründe yer alan diğer araştırmalarla karşılaştırılarak benzer ve farklı yönleriyle ortaya konulmuştur.

Değerlerimiz ve fikirlerimiz, içinde yaşadığımız toplum ve kültürden etkilenir. Hepimiz toplumu oluşturan bir ailenin fertleri olarak aile çevresinden ve bağlı bulunduğumuz sosyal grubun değer ve düşünce yapısından etkileniriz (Wells vd. 2000, s. 92). Beğenilerimiz ve tüketim alışkanlıklarımız da bu aidiyet ile bilişsel ve duyuşsal değerlendirmelerimizin etkisi ile şekillenir. Reklamcılar, hem kültürel değerlerle uyumlu hem de tüketicinin bam teline basacak reklam mesaj stratejileri geliştirerek, çoklu mecralar aracılığı ile tüketicinin dikkatini çekmeye çalışmaktadır.

Çoklu mecra içinde geleneksel medyanın en etkin araçlarından biri olan televizyonun günümüzde her evde bulunması televizyon reklamlarının popülaritesinin daha uzun süre süreceğini göstermektedir. Alwitt ve Prabhaker (1992) çalışmalarında televizyonun, bilgi işlevi, haz işlevi, sosyal öğrenme işlevi ve değer işlevi olduğunu, televizyon reklamlarının; bireysel değerlendirmelerede farklılık gösterebileceğini örneğin, eğlence kaynağı, fayda odaklı ya da hoşlanılma (hedonik işlev) gibi olumlu değerlendirmelerin yanı sıra rahatsızlık duyma şeklinde de olabileceğini vurgulamıştır. Çalışmanın amacı doğrultusunda deneklerin yaş aralığı geniş tutulduğundan, internet reklamcılığı yerine televizyon reklamı kullanılması uygun görülmüştür. Böyle bir kararın alınmasına esas dayanak; üst yaş grubunda internet kullanıcısı olmayanların olabileceği ve bu kişilerin daha önce seçilen reklama, maruz kalmamış olabilecekleri varsayımıdır. Ayrıca bu şekilde katılımcıların beğeni sıfatları arasında yer alan 'çok gösterildi...yeni' ifadesini kodlamada gerçekçi bir yanıt verebilmesi sağlanmıştır. Çalışmada tek bir marka (Tadım) ve reklam (Türkiye'nin En Büyük Sosyal Ağı) üzerinden izleyicilerin reklam beğeni değişkenlerinin neler olduğu bir model ile test edilmeye çalışılmıştır.

İzleyici algısının bir ölçümü olarak beğeni, günümüzde git gide önem kazanmaktadır. Reklam beğenilirliği literatürü incelendiğinde beğeni, 'Reklamı izledikten sonra ne hissettiniz' sorusuyla ya da beğeni sıfatları kullanılarak reklamı tanımlama şeklinde ölçülmüş ve araştırmaların çoğunda beğeninin ikna, hatırlama ve satın alma üzerine etkisi ve bu kavramlarla ilişkisi tartışımıştır. Bu çalışmada beğeni, diğer çalışmalarda (Biel 1998; Biel ve Bridgewater 1990; Smit vd. 2006; Greene 1991 McKechnie, Leather ve Manon 1994) olduğu gibi beğeni sıfatları ile ölçülmüş ancak beğeninin etkilediği kavramlar üzerine değil, beğeniyi oluşturan girdiler incelenerek, konuya dair alanda eksik kalan yönler tamamlanmaya çalışılmıştır.

Aaker ve Stayman (1990) faktör analizi yaptıkları çalışmalarında; sıfatların eğlenceli/ esprili, bilgilendirici/etkililik, sinir bozucu/saçma, sıkıcı, samimi, hayat dolu, tanıdık, inanılır ve kafa karıştırıcı olmak üzere dokuz boyutta toplandığını tespit etmişlerdir. Bu boyutları reklam beğenilirliği ve etkililiği ile regresyona soktuklarında ise reklamların hepsinde kullanılan ortak bir faktör olmadığını ancak 'bilgilendirici/etkililik' faktörünün en önemli faktör olduğu sonucuna ulaşmışlardır. Araştırmada soru formunda yer alan 'Tadım Türkiye'nin En Büyük Sosyal Ağı' reklamlarını izleyen denekler, 23 beğeni 
sıfatından en çok eğlendirici, saçmalamıyor, sinirlendirmiyor ve anlaşıır sıfatlarını kullanarak, reklamı tasvir etmişlerdir. İzleyiciler eğlenirken reklamın saçma olmamasını ve anlaşııı olmasını önemsemiş sadece reklamın yeni ve ikna edici olduğu konusunda kararsız bir yaklaşım sergilemişlerdir. Danbury ve Mortimer (2011), beğenilirliğin reklamın anlaşılmasıyla ilişkili oluğunu vurgulamış benzer bir şekilde Du Plessis de geliştirdiği COMMAP teorisinde, beğenilen reklamların anlaşılır ve eğlenceli olduğunu göstermiştir.

Reklam Araştırmaları Vakfının (ARF) yaptığı çalışmada, izleyicilerin reklamı beğenmesinde, eğlendirici unsurun yanında bilgilendirici yönüne de dikkat ettikleri vurgulanmıştır. Greene (1992) ise çalışmasında beğenilirliğin geleneksel eğlence kavramı ile daha az ilişkili olduğunu, izleyicilerin beğeni ile ilgili soruları eğlence değerindense iletişim ve ikna yönlü yanıtlama eğilimi gösterdiklerini bulmuştur. Bu çalışmada da ARF'nin ve Mehta'nın (2000) çalışmaları ile benzer şekilde reklam, eğlenceli ve bilgilendirici olduğunda genel anlamda beğenilir ve değerine inanılır görüşünü destekler bulgulara ulaşıImıştır.

Bir reklama yönelik beğeniyi açıklamada demografik, psikografik ve kişilik özellikleri değişkenlerinin işlemeyişi; beğeninin kişilerin yaşına, cinsiyetine, eğitimine, kişisel özelliklerine ve hayata bakış açılarına göre farklılaşmadığını göstermesi açısından önemlidir.

Reklam kampanyalarının kaderini belirlemede beğeni, eşik bekçisi rolünü üstlenmekte ve beğenilen reklamların klasik şartlanma yoluyla markaya transfer edileceği ve bu durumun satışa yansıyacağı şeklinde bir hiyerarşi olduğu görüşü benimsenmektedir. Reklamda klasik şartlanma yaklaşımını açıklarken Edell ve Burke (1984), bir reklama yönelik tutumun bir markaya yönelik tutumu etkileyebilmesinde reklama sık maruz kalmanın etkisi olduğunu savunur. Çalışmada odak grup görüşmesi katılımcılarının geneli, reklamı beğenmeseler de markalarından vazgeçmeyeceklerini belirtmiştir. Ayrıca katılımcıların birden fazla reklama maruz kaldıkları anlaşıldığından (reklamı yeni olarak değerlendirmede kararsız kaldıkları) klasik yaklaşımın esasında reklamların bütününde işlemeyebileceğini göstermesi açısından önemlidir. Ancak modelde yer alan her iki değişkenin, reklama ve markaya yönelik tutumun, beğeniyi açıklamada anlamlı olduğu bulunmuştur.

Modelde yer alan bir diğer değişken reklamda yaratıcı strateji, reklam içeriğinin (mesaj) ve reklam sunumunun (uygulama) bir arada değerlendirilmesidir. Wells ve diğerleri (2000) yaratıcı uygulamanın; mesajın nasıl görüleceği, okunacağı ve sesi gibi son biçimini içeren, mesaj biçimi, reklamın tonu ve üretimi gibi belli niteliklerden oluştuğunu belirtmiştir. İzlerkitlenin dikkatini çekmede, yaratıcı strateji belirleyici rol oynamakta ve pazarlamacılar hedef kitleye yönelik mesajın ne olacağı ve nasıl sunulacağına yönelik geliştirdikleri strateji ile reklam beğenisini sağlamayı amaçlamaktadırlar.

Belirli ürünlerde belirli reklam çekiciliklerinin kullanımının daha uygun olduğunu ifade eden Biel ve Bridgewater (1990), tüketicilerin yiyecek-içecek reklamlarını diğer ürün reklamlarına göre daha fazla beğendiklerini ortaya koyarken Aaker ve Bruzzone (1985), De Pelsmacker ve Van den Berg (1998) tüketicilerin bazı ürün kategorilerini diğerlerinden daha irrite edici değerlendirebildiklerini bulmuştur. Benzer şekilde Raghu- 
nathan ve Irwin de (2001), ürün kategorisi memnuniyetinin, tüketici değerlendirmelerini önemli ölçüde etkilediğini belirtmiştir (Geuens vd., 2011: s. 419). Çalışmada yiyecekiçecek kategorisinde tek bir ürün reklamı deneklere izletilmiştir. Biel ve Bridgewater'ın çalışmasını destekler nitelikte yiyecek (çerez-şekerleme) kategorisindeki ürünün reklamına yönelik beğeni sıfatlarının ortalaması 5,75 gibi yüksek bir ortalamaya sahiptir. Reklamda geçmişle günümüzü karşılaştıran, nostalji ve mizah çekiciliğinin ağırlıklı olarak kullanıldığı reklam, bu ortalama ile izlerkitlenin reklamı beğendiğini göstermektedir. Soru formunda yer alan yaratıcı strateji ifadelerine yönelik en yüksek ortalama; reklam mesajının yaratıcı bulunması ve ifadelerin etkili kullanıldığı görüşünün benimsenmesidir. Ayrıca denekler, reklamda kullanılan kişilerin etkili bir bağlam içinde gösterildiğini belirtmelerine ve prodüksiyonu beğenmelerine rağmen reklamın vaadi olduğu konusunda kararsız bir tutum göstermişlerdir.

Kemp ve arkadaşları (2012) yaptıkları araştırmada duygu dilinin reklamlarda kullanılması sonucunda katılımcılarda reklama yönelik olumlu duygunun açığa çıkabileceğini ileri sürmüştür. Reklama yönelik duygusal tepkiler reklama yönelik olumlu tutumu, davranışsal niyeti ve nihayetinde ürüne yönelik beğeniyi açığa çıkarabilir. Youn (1998) reklamcıların duygusal ürün yaklaşımında imaj eğilimini (image-oriented), ürünün faydacı yönünü ortaya koymada ise rasyonel ve mesaj yönelimli çekicilikleri kullandıklarını bulmuştur (Geuens vd. 2011, s. 419). Duygusal reklam (kişisel tatmin, sosyal kimlik, duyusal uyaran ve benlik geliştirme, mizah, eğlence, nostalji, seks, öfke ve diğer duygular) ve rasyonel reklam (ürün/hizmet fiyatı, kalite, işlev, ürün, satın alma zamanı ve yeri, satış promosyon bilgisi, tat bilgisi, ürün içeriği, paketleme, tüketiciye vaat, garanti, araştırma, özel teklifler ve ürünün güvenilirliği) arasındaki farklılık, reklamda kullanılan çekiciliklere dayanmaktadır (Chaoying vd. 2011, s. 45). Tadım markasının 'Türkiye'nin En Büyük Sosyal Ağı' reklamında; ürün aracılığı ile arkadaşıkların kurulması, bir araya gelerek paylaşımda bulunulması, ailenin bir aradalığını sağlaması gibi kullanıcı imajına yönelik görüntüler ile nostalji, mizah ve sıcaklık çekiciliğinin kullanılması, yaşamdan kesitlerin hikayeleştirici bir ton kullanılarak anlatılması duygusal reklamı çağrıştırmaktadır ancak ürün gösterimi ve reklamın iddiasının (Türkiye'nin en büyük sosyal ağı) olması, karma çekicilik olabileceği fikrini de güçlendirmektedir.

Son söz olarak bu çalışmada bir reklama yönelik beğeni; kişilerin demografik, psikografik ve kişilik özelliklerine bağlı olmayıp, reklama, markaya ve yaratıcı stratejiye yönelik tutumlar aracılığı ile şekillenen bir yapı olarak tanımlanabilir.

\section{Kaynakça}

Aaker, D.A ve Bruzzone, D.E (1981). Viewer perceptions of Prime-Time Television Advertising. Journal of Advertising Research, 21(5): s. 15-23.

Aaker, D.A. ve D.M. Stayman. (1990). Measuring Audience Perceptions of Commercials and Relating Them to Ad Impact. Journal of Advertising Research, 30 (4): s. 7-17.

Aitken, R., Lawson, R. ve Gray, B. (2003). Advertising Typologies: A Meta Analysis. Advertising/ Marketing Communications Issues Track. ANZMAC 2003 Conference Proceedings Adelaide 1-3 December. 
Alwitt, L.F. ve Prabhaker, P.R. (1992). Functional and Belief Dimensions of Attitudes to Television Advertising: Implications For Copytesting. Journal of Advertising Research, 30-42.

Ambler, T. ve Burne, T. (1999). The Impact of Affect on Memory of Advertising. Journal of Advertising Research, 39 (2): s. 25-34.

Aytaç, S. (2009). İnsanı Anlama Çabası. Bursa: Ezgi Kitabevi.

Batra, R. ve Ray, M. (1986). Affective Responses Mediating Acceptance of Advertising. The Journal of Consumer Research, 13(2): s.234-249.

Biel, A. ve Bridgewater, C.A. (1990). Attributes of Likeable Television Commercial. Journal of Advertising Research, 30 (3): s. 38-44.

Brengman, M.; Geuens, M. ve De Pelsmacker, P. (2001). The Determining Factors of Brand Confusion. Journal of Marketing Communications, 7(4): s. 231-243.

Burke, M.C.ve Edell, J.A. (1989). The impact of Feelings on Ad Based Affect and Cognition. Journal of Marketing Research, XXVI: s. 69-83.

Chaoying, T., Jian, S. ve Ille, F.R (2011). Information Handling Styles, Advertising and Brand Attitude: A Chinese Brand Case Study. International Journal of China Marketing, 1(2): s. 45-56.

Chung, H. ve Zhao, X (2003). Humor Effect on Memory And Attitude: Moderating Role of Product İnvolvement. International Journal of Advertising, 22(1): s.117-44.

Costa, P.T. ve McCrae, R.R. (1992). Four Ways Five Factors Are Basic. Person Individ. Diff. 13(6): s. 653-665.

Dahl, S. (2004). Cross Cultural Advertising Research: What Do We Know About The Influence Of Culture On Advertising?. Middlesex University Business School Discussion Paper, 1-2.

Danbury, A. ve Mortimer, K. (2011). Affective Involvement in Advertising Effectiveness: Implications for Interpretation Of Print Advertisements. 10th International Conference on Research in Advertising (ICORIA 2011), Berlin, 23-25 June.

Demirtaş Madran, H.A. (2012). Tutum, Tutum Değişimi ve İkna. Ankara: Nobel Kitabevi.

DuPlessis, E.C. (1994). Understanding and Using Likeability. Journal of Advertising Research, 34(5): 3-10.

Durmuş, B., Yurtkoru, E.S. ve Çinko, M. (2011). Sosyal Bilimlerde SPSS'le Veri Analizi, Dördüncü Baskı, İstanbul: Beta.

Dutta- Bergman, M.J. (2006). The Demographic and Psychographic Antecedemts of Attitude Toward Advertising. Journal of Advertising Research, March, s. 102- 112.

Edell, J.A. ve Burke, M.C. (1987). The Power of Feeling in Understanding Advertising Effects. Journal of Consumer Research, (14): s. 421-433.

Elpeze Ergeç, N. (2004). Televizyon Reklamlarına Yönelik Şüphe (İkna Bilgi Modelinin Yorumlanması). Anadolu Üniversitesi Yayınları, No: 53.

Erdoğan, İ. (2012). Pozitivist Metodoloji ve Ötesi. İstanbul: Erk Yayınları.

Fam, K.S. ve Waller, D.S. (2006). Identifying Likeanle Attributes: Aqualitative Study Of Television Advertisements in Asia, Journal of Market Research, 9(1): s. 38-50.

Gardner, M.P. (1985). Does Attitude Toward the Ad Affect Brand Attitude Under a Brand Evaluation Set? Journal of Marketing Research, 22: s. 192-8.

Gegez, E. (2007). Pazarlama Araştırmaları, İstanbul: Beta Basım.

Geuens, M. ve De Pelsmacker, P. (1998). Feelings Evoked by Warm, Erotic, Humorous or 
Non-Emotional Print Advertisements for Alcoholic Beverages. Academy of Marketing Science Review, 19 (1): s. 1-32.

Goldberg, M.E. ve Gorn. G.J. (1987). Happy and Sad TV Programs: How They Affect Reactions to Commercials. Journal of Consumer Research, (14): s. 387-403.

Greene, W.F. (1992). Observations: What Drives Commercial Liking? An Exploration of Entertainment vs. Communication. Journal of Advertising Research, 32(2): s. 65-68.

Haley, R.I ve A.L. Baldinger. (1991). The ARF Copy Research Validity Project. Journal of Advertising Research, 31 (2): s. 11-32.

Hollis, N.S. (1995). Like It or Not, Liking is ot Enough. Journal of Advertising Research, 35(5): S. 7-16.

Homer, P.M. (1990). The Mediating Role Of Attitude Towards the Ad: Some Additional Evidence. Journal of Marketing Research, 27: s. 78-86.

Kennedy, R., Byron, S. ve Campbell, R. (1999). Does Ad Liking Improve Correct Branding?. 28 th European Marketing Academy Conference. Humboldt University.

Leather, P., McKehnie, S. ve Amirkhanian, M. (1994). The Importance of Likeability as a Measure Of Television Advertising Effectiveness. International Journal of Advertising, 13(3): s. 265-280.

Levitt, T. (1983). Globalization of Markets. Harvard Business Review, 61 (3): s. 92-102.

Lutz, R.J. (1985). Affective and Cognitive Antecedents of Attitude Toward the Ad: A Conceptual Framework, in Psychological Processes and Advertising Effects: Theory, Reearch and Application, Alwitt, L.F ve Mitchell, A.A eds. Hillsdale, NJ: Lawrence Erlbaum Associates, s. 45-63.

Manrai, L.A., .Broach, V.C ve Manrai, A.K. (1992). Advertising Appeal and Tone: Implications for Creative Strategy in Television Commercials. Journal of Business Research, 25: 43-58.

Mckechnie, S., Leather, P. ve Manon. (1994). The Importance of Likeability as a Measure of Television Advertising Effectiveness. International Journal of Advertising, 13(3): s. 265-289.

McKenzie, S.B., Lutz R.J. ve Belch, GE (1986). The Role of Attitude Toward The Ad as a Mediator of Advertising Effectiveness: A test of Competing Explanations. Journal of Marketing Research, 23(2): s. 130-43.

McKenzie, S.B., Lutz, R.J. (1989). An Empirical Examination of The Structural Antecedents of Attitudes Toward The Ad in an Advertising Pretesting Context. Journal of Marketing, 53(2): s. 48-65.

Mitchell, A.A. ve Olson, J. C. (1981). Are Product Attribute Beliefs The Only Mediator Of Advertising Effects On Brand Attitude. Journal of Marketing Research, XVIII: s. 318-332.

Mooij, Marieke K. de (1998), Global Marketing and Advertising : Understanding Cultural Paradoxes.Thousand Oaks, Calif.: Sage Publications.

Muehling, D.D. ve McCann, M. (1993) Attitude Toward the Ad: A review. Journal of Current Issues and Research in Advertising, 15( 2): s. 25-58.

Moldovan, S.E. (1985). Copy Factors Related to Persuasion Scores. Journal of Advertising Research, 24 (6): s. 16-22.

Nguyen, B., Melewar, T.C. ve Chen, J. (2013). The Brand Likeability Effect: Can Firms Make Themselves More Likeable? Journal of General Management, 38(3): s. 25-50.

Okan, T., Koparan, E. ve Nas İlhan, T. (2016). Yönetim Kurulu Çeşitliliği ve Kurumsal Sosyal 
Sorumluluk Söylemleri Arasındaki İlişki: Kurumsal Çevrenin Moderatör Etkisi. Ankara Üniversitesi SBF Dergisi, 71(2): s. 465-509.

Pelsmacker de, P., Geuens, M. ve Van den Bergh, J. (2004) Marketing Communications. A European Perspective. Harlow: Financial Times/Prentice-Hall.

Pollay, R.W. (1983). Measuring The Cultural Values Manifest in Advertising. Current Issues and Research in Advertising, 6(1): s. 71-92.

Schlinger, M.J. (1979). A Profile of Responses to Commercials. Journal of Advertising Research, 19 (2): s. 37-46.

Shimp, T. (1976). Methods of Commercial Presentation Employed By National Television Advertisers. Journal of Advertising, 5(4): s. 30-36.

Stewart, D.W. ve Furse, D. (1984). Analysis of The Impact of Executional Factors on Advertising Performance. Journal of Advertising Research, 24: s. 21-32.

Walker, D. ve Dubitsky, T (1994). Why Liking Matters. Journal of Marketing Research, 34(3): s. 9-18.

Wells, W.D., Leavitt, C ve McConville, M. (1971). A Reaction Profile For TV Commercials. Journal of Advertising Research 11(6): s.11-17.

Wells, W., Burnett, J.ve Moriarity, S. (2000). Advertising Principles and Practice. Prentice Hall. Praet, C. (2007). The Nature and Role of Advertising Likeability: A Cross Cultural Investigation. http://barrel.ih.otaru-uc.ac.jp/bitstream/10252/213/1/ER_58\%282-3\%29_125-160.pdf (Erişim Tarihi: 25.09.2014).

\section{İnternet Kaynağı}

http://antalya.yerelnet.org.tr/il_ilce_nufus.php?iladi=ANTALYA (01.08.2016). 